\title{
A STUDY ON CUSTOMER AWARENESS LEVEL AND SATISFACTION OF HEALTH INSURANCE POLICIES IN CHENNAI CITY
}

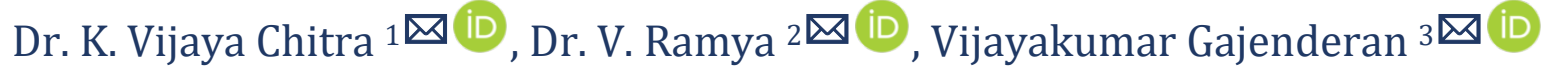 \\ ${ }^{1,2}$ Assistant Professor of Commerce, Sir Theagaraya College, Chennai-600 021, India \\ ${ }^{3}$ Assistant Professor \& Research Supervisor, Department of Commerce, Sir Theagaraya College, \\ Chennai-600 021, India
}

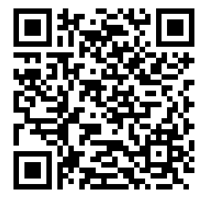

DOI: https://doi.org/10.29121/granthaalayah.v9.i3.2021.3792

Article Type: Research Article

Article Citation: Dr. K. Vijaya Chitra, Dr. V. Ramya, and

Vijayakumar Gajenderan. (2021). A

STUDY ON CUSTOMER AWARENESS

LEVEL AND SATISFACTION OF

HEALTH INSURANCE POLICIES IN

CHENNAI CITY. International

Journal of Research -

GRANTHAALAYAH, 9(3), 156-161.

https://doi.org/10.29121/granthaa

layah.v9.i3.2021.3792

Received Date: 14 March 2021

Accepted Date: 31 March 2021

Keywords:

Health Insurance

Customer Awareness Level

Satisfaction

\section{ABSTRACT}

The study proposed to examine product awareness of health insurance products on their satisfaction among the customers in Chennai city. The study employed primary and secondary data. The primary data is collected from the customers of health insurance policyholders in Chennai city. The responses are gathered from the policyholders through the welldesigned questionnaire copy. The purpose of the secondary data is to familiarize the research area. The secondary information is collected from the research articles, magazines, Insurance Regulatory Development Authority, and daily newspapers. The study used a convenience sampling method. Overall, 300 questionnaires are distributed, out of which the customers return 283 filled responses. The filled answers are checked and finalized the entire 283 samples for the final study. Therefore, the total sample size of the study is 283. The study used frequency distribution, onesample t-test, and General Linear Model of Multivariate Tests. The study confirmed that the customers are well aware of the health insurance companies and their products. The study also creates a significant relationship between awareness about health insurance products and the level of satisfaction.

\section{INTRODUCTION}

The rise in health care costs has persuaded many people to buy a health insurance policy. There has been a change in people's perception from seeing health insurance as a protection tool to an investment tool- a provision from where future health expenses can be bear medical purposes. People also opt for a regular health check-up and spending towards health. Apart from these, increased income level, price liberalization, reduction in bureaucracy, and private healthcare introduction resulted in more popularity about health insurance. There are four public sector insurance companies, 18 private-sector insurers, six stand-alone insurance companies, and two specialized insurers providing health insurance coverage. The private sector general insurers launched many innovative products like critical illness plans, family floater policies, top-up policies. Despite the development of the health insurance sector, a difference in awareness among people is seen based on their socio-economic profile and residence location. Many middle and lower socio-economic class families are caught under debt trap due to out-of-pocket expenses connected with hospitalization. The absence of health insurance coverage may be attributed either due to a lack of financial position to acquire the policy or a lack of awareness regarding the need to have proper insurance coverage. This

(C) 2021 The Author(s). This is an open access article distributed under the terms of the Creative Commons Attribution License, which permits unrestricted use, distribution, and reproduction in any medium, provided the original author and source are credited. 
Dr. K. Vijaya Chitra, Dr. V. Ramya, and Vijayakumar Gajenderan

paper examines the level of understanding of people towards health insurance schemes and the extent to which awareness of health insurance products leads to customers' satisfaction.

\section{LITERATURE REVIEW}

(Shet, Qadiri, Saldanha, Kanalli, \& Sharma, 2019) point out that many were not aware of health insurance. It shows the gap in communication between the health personals and the general population. Even if they were aware, a little more did not avail of any health insurance. It shows the non-existence or drawbacks in health insurance that are available. Health insurances are the best way to help people reduce their financial burden and reduce the gap of health care utilization among the rich and the poor. Hence it is important to educate the community regarding the best health insurance available to benefit from it.(Deepa, Geeta, \& Subramanian, 2018) mentioned that some form of health insurance should cover everyone. Millions of Americans are uninsured in the division due to high premium costs. Many are forced to pay these sky-scraping health costs out of pocket, creating more problems medically and monetarily. Indian Health insurance or medical insurance sector has been growing since the country's economic reforms. The reason medical insurance, has grown is that it ensures good medical care from reliable health care institutions. With numerous companies offering health insurance and various health insurance plans on the offer, it is hard to decide which plan. This competitive market needs to compare policies to find the best health insurance policies or the best medical insurance plans. (Nema \& Jatav, 2017) found out which are serious for customer retention in the health insurance industry. The results specify that innovative products, competitive prices, prompt services of companies, employee responsiveness and empathy, the tangibility of services, and reliability of services offered are various determinants of customer retention found crucial in this study.(Kala, S. \& Jain, 2015) concluded that respondents are aware of health insurance but denied taking health insurance or medical-claim policies. People trust more in public general insurance companies than private general insurance companies to avail themselves of the health insurance policies. According to the health insurance companies, respondents were not aware of health insurance policies terms and conditions and are not transparent. Thus, health insurance still has wider scope in India but is supposed to be easy to understand and accessible.(Kansra, 2015) reveals that health insurance is also associated with different misconceptions. The need of the hour is to supply clear, comparative information via multiple and readily accessible channels. Once the penetration of health insurance increases, the catastrophic outof-pocket health expenditure will decline, improving the country's quality of life. (Tiwari \& Gupta, 2014) Communication and follow-up should also be proper with the policyholders with their satisfaction. Claim if the insurance policy should be on time since when the patient is in hospital, he needs treatment, so the health insurance company plans the policyholder's claiming facility. The company does the advertising for the policy to be aware properly to the customer and provide minimum premium and best benefits. Communication channels should be proper, the information given by business personnel's to the client is clear and true. (Choudhary et al., 2013) Education, socio-economic status, and occupation were favourable determinants for opting for health insurance. The reason for opting for health insurance was mainly related to medical care and financial aspects. Media seemed to have played an important part in the dissemination of material. (Maumita Ghosh, 2013) shown that educated people are unresponsive to invest more in health insurance products. Rather they desire to invest more in other modes of savings, giving them a high return. Simultaneously, examination of Canonical correlation gives us the design that the individuals' financial position and ability have an sufficient association with the hazards of illness as a whole. (Aggarwal, Kapoor, \& Gupta, 2013) uncovering patterns for raising productivity, and leaders across health sectorspublic, private, and social - should take heed. In this paper, we would be highlighting the various recent innovations in the insurance sector. The study will also be discussing the upcoming innovations in the health sector and its complexities and various challenges ahead. (Gurunathan, 2010) Despite being aware of various private companies, taking health insurance policy was family protection and tax savings being of lesser importance. (Garg, 2005) health insurance claimants have trooped claims as they faced some form of illness. Respondents' satisfaction with claim settlement and various other health insurance coverage features has been scrutinized and compared across public and private sector companies. The policyholders have commonly complained of delay in policy issue, excessive documentation, non-responsiveness and non-cooperativeness on the part of company and its officials, delay/ rejection in case of claim settlement, lack of transparency, etc. In light of the findings, the study gives suggestions to improve overall experience of the health insurance policyholders. 


\section{STATEMENT OF THE PROBLEM}

Health insurance delivers access to and financial protection against medical costs in an accident and chronic illness that a specialist needs ongoing treatment. Medical coverage also defends individuals who need immediate care for a broken leg, stroke, or heart attack. Buying a health insurance policy for individuals and family is essential because medical care is expensive, especially in private sector hospitals. Due to environmental changes, many diseases are spreading to humans quickly. The illness severely affected the individuals and family. Presently, medical expenses are very high in modernized hospitals. Bearing the hospital expenses of the middle class and upper-middleclass people is very tough. The medical care policy is essential for individuals to avoid the unexpected financial burden. An acceptable health insurance policy would usually cover expenses made towards doctor consultation fees, costs towards medical tests, ambulance charges, hospitalization costs, and even post-hospitalization recovery costs to a certain extent. Increasing medical cost is the primary cause for the financial instability among poor and middleclass people. The majority of them depend either on private loans or dispose of their assets to meet the medical burden. Lack of awareness about the health insurance cost aspect in payment of premium and claim processing prevents many customers from taking a health insurance policy. Similarly, customer satisfaction is determined by their perception of the product primarily built from awareness. Hence, it is essential to analyze customers' attention regarding the health insurance products and the inter-relation between understanding and customer satisfaction.

\section{OBJECTIVES OF THE STUDY}

1) To study the level of awareness of health insurance products among the customers

2) To assess the relationship between awareness of health insurance policies and health insurance customers' satisfaction.

\section{STATEMENT OF HYPOTHESES}

1) There is no adequate level of awareness about the Health Insurance Products among the Consumers in the study area

2) There is no significant relationship between the level of awareness about health insurance products and the level of satisfaction

\section{RESEARCH METHODOLOGY}

The present study is focused on measuring the Customer Awareness Level and Satisfaction of Health Insurance Policies in Chennai City. The study employed primary and secondary data. The primary data is collected from the customers of health insurance policyholders in Chennai city. The responses are gathered from the policyholders through the well-designed questionnaire copy. The purpose of the secondary data is to familiarize the research area. The secondary information is collected from the research articles, magazines, Insurance Regulatory Development Authority, and daily newspapers. The study used a convenience sampling method. Overall, 300 questionnaires were distributed, out of which the customers return 283 filled responses. The filled answers are checked and finalized the entire 283 samples usable for the final study. Therefore, the total sample size of the study is 283. The study used frequency distribution, one-sample t-test, and General Linear Model of Multivariate Tests

\section{RESULTS AND DISCUSSION}

Table 1: Demographic Profile of Customers

\begin{tabular}{|c|c|c|}
\hline Gender & Frequency & Percent (\%) \\
\hline Male & 175 & 61.8 \\
\hline Female & 108 & 38.2 \\
\hline Total & 283 & 100.0 \\
\hline Age & & \\
\hline
\end{tabular}


Dr. K. Vijaya Chitra, Dr. V. Ramya, and Vijayakumar Gajenderan

\begin{tabular}{|c|c|c|}
\hline Up to 30 & 89 & 31.4 \\
\hline $31-35$ & 74 & 26.1 \\
\hline $36-40$ & 65 & 23.0 \\
\hline Above 40 & 55 & 19.4 \\
\hline Total & 283 & 100.0 \\
\hline \multicolumn{3}{|l|}{ Marital status } \\
\hline Single & 101 & 35.7 \\
\hline Married & 182 & 64.3 \\
\hline Total & 283 & 100.0 \\
\hline \multicolumn{3}{|c|}{ Educational Qualification } \\
\hline Up to HSC & 42 & 14.8 \\
\hline UG & 82 & 29.0 \\
\hline $\mathrm{PG}$ & 81 & 28.6 \\
\hline Professional & 78 & 27.6 \\
\hline Total & 283 & 100.0 \\
\hline \multicolumn{3}{|c|}{ Occupation } \\
\hline Private & 88 & 31.1 \\
\hline Government & 81 & 28.6 \\
\hline Business & 79 & 27.9 \\
\hline Professional & 35 & 12.4 \\
\hline Total & 283 & 100.0 \\
\hline \multicolumn{3}{|l|}{ Family Income } \\
\hline Up to 3 Lakhs & 78 & 27.6 \\
\hline $3.1-6.0$ Lakhs & 90 & 31.8 \\
\hline $6.1-9.0$ Lakhs & 77 & 27.2 \\
\hline$>9$ Lakhs & 38 & 13.4 \\
\hline Total & 283 & 100.0 \\
\hline
\end{tabular}

Table 1 shows the demographic profile of customers in the study area. Out of 283 customers, most 175 (61.8\%) customers are male category, and 108 (38.2) are female. Regarding the age category of customers, the majority, $31.4 \%$ customers, are in the age group of up to 30 years. The age group followed by $31-35$ years $(26.1 \%), 36-40$ (23\%), and above 40 years (19.4). Marital status concern, the majority $64.3 \%$ of the customers, is married, and $35.7 \%$ of the customers are unmarried. As for educational qualification concern, the majority $29 \%$ of the customer's educational background were undergraduates, followed by $28.6 \%$ of the customer's educational background were post-graduates, $27.6 \%$ of the customer's educational qualification were professional, and $14.8 \%$ of the customer's educational qualification were up to HSC. Regarding the occupational status concern, the majority, 31.1\%, of the customers are working in private organizations. It is followed $28.6 \%$ of the customers are working in government, $27.9 \%$ of the customers are engaging themselves an individual business, and $12.4 \%$ of the customers are engaging the professional services. The frequency distribution also exhibits that majority $31.8 \%$ of the customer's annual income is Rs.3.1 Lakhs - Rs.6.0 Lakhs, followed by $27.6 \%$ of the customer's annual income is up to 3.0 lakhs, $27.2 \%$ of the customer's annual income is 6.1 - 9.0 Lakhs, and $13.4 \%$ of the customer's annual income is above nine lakhs.

\section{Null Hypothesis-1}

There is no adequate level of awareness about the Health Insurance Products among the Consumers in the study area

Table 2: One-sample t-test for Awareness of Health Insurance Products

\begin{tabular}{|c|c|c|c|c|c|}
\hline Awareness Level of Health Insurance Products & $\mathrm{N}$ & Mean & SD & $\mathrm{t}$ & $\mathrm{p}$ \\
\hline Features of Health Insurance product & 283 & 3.73 & 1.013 & 12.143 & $<0.001^{* *}$ \\
\hline Policy Terms and Conditions & 283 & 4.36 & 0.885 & 25.788 & $<0.001^{* *}$ \\
\hline Diseases covered & 283 & 4.18 & 0.826 & 24.106 & $<0.001^{* *}$ \\
\hline Hospitals Linked & 283 & 3.66 & 1.104 & 10.014 & $<0.001^{* *}$ \\
\hline
\end{tabular}


A Study on Customer Awareness Level and Satisfaction of Health Insurance Policies in Chennai City

\begin{tabular}{|c|c|c|c|c|c|}
\hline Third Party Administrators & 283 & 3.87 & .974 & 15.078 & $<0.001^{* *}$ \\
\hline Renewal options of policy & 283 & 3.84 & 1.140 & 12.357 & $<0.001^{* *}$ \\
\hline Procedures for Claim settlement & 283 & 3.92 & 1.235 & 12.469 & $<0.001^{* *}$ \\
\hline Filing of grievances & 283 & 3.83 & .888 & 15.659 & $<0.001^{* *}$ \\
\hline
\end{tabular}

Table-2 shows the one-sample t-test for Awareness of Health Insurance Products among the customers in Chennai city. The mean values of awareness about health insurance products range from 3.66 to 4.36 , with a standard deviation ranging from 1.104 to 0.885 . The results indicate that the entire statements of awareness of health insurance products are $<0.001$. Therefore, the proposed null hypothesis was rejected at a $1 \%$ level of significance. Consequently, the study confirmed that the customers are well aware of the health insurance companies and their products.

\section{Null Hypothesis-2}

There is no significant relationship between the level of awareness about health insurance products and the level of satisfaction

Table 3: General Linear Model of Multivariate Tests based on awareness - Level of Customer Satisfaction

\begin{tabular}{|c|c|c|c|c|}
\hline Effect & & Value & F & Sig. \\
\hline \multirow{3}{*}{ Awareness } & Pillai's Trace & .135 & 2.629 & $.002^{* *}$ \\
\cline { 2 - 5 } & Wilks' Lambda & .823 & $2.616^{\mathrm{b}}$ & $.002^{* *}$ \\
\cline { 2 - 5 } & Hotelling's Trace & .146 & 2.603 & $.002^{* *}$ \\
\cline { 2 - 6 } & Roy's Largest Root & .096 & $2.921^{\mathrm{c}}$ & $.010^{*}$ \\
\hline
\end{tabular}

Significance at 5 percent level

Table 3 highlights the results of the General Linear Model of Multivariate Tests based on Awareness level of Health Insurance Products and Level of Customer Satisfaction. It is identified from the above Table-3, the significance value of all the four tests is $<0.05$; the null hypothesis $\left(\mathrm{H}_{0)}\right.$ is is rejected at a 5 percent significance level. The study establishes a significant relationship between awareness about health insurance products and the level of satisfaction.

\section{CONCLUSION}

The study focused on assessing the customer awareness level and Satisfaction of Health Insurance Policies in Chennai city. It is observed from the study; the customers felt that the health insurance policies are essential and also provide the financial protection of medical expenses. The study's outcome also exhibits that the customers are well-aware about the, i.e., hospitalization expenses, daycare procedures, domiciliary expenses, and ambulance charges. The study also originated that the customers are well aware of the Health Insurance products. The study also initiates a significant relationship between awareness about health insurance products and the level of satisfaction.

\section{SOURCES OF FUNDING}

This research received no specific grant from any funding agency in the public, commercial, or not-for-profit sectors.

\section{CONFLICT OF INTEREST}

The author have declared that no competing interests exist. 


\section{ACKNOWLEDGMENT}

None.

\section{REFERENCES}

[1] Aggarwal, A., Kapoor, N., \& Gupta, A. (2013). Health 9Insurance: Innovation and Challenges Ahead. Global Journal of Management \& Business Studies, 3(5), 475-480.

[2] Choudhary, M. L., Goswami, K. I., Khambhati, S. B., Shah, V. R., Makwana, N. R., \& Yadav, S. B. (2013). Awareness of Health Insurance: Its Related Issues in Rural Areas of Jamnagar District. National Journal of Community Medicine Volume, 4(2), 267-271. Retrieved from www.njcmindia.org

[3] Deepa, S., Geeta, T., \& Subramanian, S. M. (2018). A Study on Health Insurance Premium, Commission \& its Growth of Select Companies in India Impact of GST on MSMEs View project Study on the financial leverage ratio of the selected industries in selected companies View project. Universal Review, 7(11), 109-121.

[4] Garg, A. (2005). Satisfaction \& Problems of Health Insurance Policyholders in India. International Journal of Banking, Risk, and Insurance, 1(2).

[5] Gurunathan, K. B. (2010). Level of Awareness on Indian Health Insurance Sector - ProQuest. Synergy, 8(2), 80-93. Retrieved from http://search.proquest.com.gate2.library.lse.ac.uk/docview/820159376

[6] Kala, S. \& Jain, P. (2015). A study on "Awareness Level of Health Insurance among people with special reference to Rajasthan." International Journal of Business Quantitative Economics and Applied Management Research, 1(12), 21-31.

[7] Kansra, P. (2015). Socio-economic Determinants of Awareness of Health Insurance Among Women: An Empirical Analysis. IUP Journal of Knowledge Management, 13(1), 71-83.

[8] Maumita Ghosh, M. G. (2013). Awareness \& Willingness to Pay for Health Insurance: A Study of Darjeeling District. IOSR Journal of Humanities and Social Science, 12(1), 41-47. https://doi.org/10.9790/08371214147

[9] Nema, J., \& Jatav, S. (2017). Determinants of Customer Retention in Health Insurance Sector. International Journal of Research \& Innovation in Social Science (IJRISS), 1(2), 6-10. Retrieved from http://www.ijriss.org/DigitalLibrary/Vol.1\&Issue2/06-10.pdf

[10] Shet, N., Qadiri, G. J., Saldanha, S., Kanalli, G., \& Sharma, P. (2019). Awareness and attitude regarding health insurance among insured and non-insured: a cross-sectional study. International Journal of Community Medicine \& Public Health, 6(9), 4071. https://doi.org/10.18203/2394-6040.ijcmph20194019

[11] Tiwari, S., \& Gupta, S. (2014). Comparative Analysis of Health System1. Global Journal of Finance and Management, 6(8), 797-800. 